\title{
PREDIKSI VOLUME AKUIFER BEBAS DI KECAMATAN BUKIT RAYA DENGAN METODE BEDA HINGGA
}

\author{
Juandi $M^{1^{*}}$, M. Syafrizal Saputra ${ }^{1}$, Usman Malik ${ }^{1}$ \\ IJurusan Fisika Fakultas Matematika dan Ilmu Pengetahuan Alam, Universitas Riau \\ Email: 1usman.malik@lecturer.unri.ac.id
}

\begin{abstract}
Abstrak
Penelitian tentang prediksi volume akuifer bebas Kecamatan Bukit Raya telah dilakukan dengan menggunakan metode beda hingga. Data kedalaman akuifer bebas menggunakan grid kontur Kecamatan Bukit Raya tahun 2015 diselesaikan secara numerik menggunakan program komputer aplikasi MATLAB versi R2009a. Tujuan penelitian ini adalah untuk menganalisa pengaruh pertambahan penduduk terhadap volume akuifer bebas di Kecamatan Bukit Raya. Hasil penelitian dapat diinformasikan pada Kecamatan Bukit Raya sebagai berikut: Volume total air bawah tanah pada tahun 2017 sebesar 10.399.615,33 m3 dan pada tahun 2021 sebesar 10.931.060,63 m3. Volume air bawah tanah yang diambil penduduk pada tahun 2017 sebesar 5.038.007,328m3 dan pada tahun 2021 sebesar 5.334.525,03 m3. Peningkatan penurunan volume air bawah tanah (residu), sehingga pada tahun 2017 peningkatan penurunan volume air bawah tanah sebesar 5.361.608 m3 dan pada tahun 2021 sebesar 5.596.535,6 m3. Dapat disimpulkan bahwa volume air bawah tanah dipengaruhi oleh perubahan kedalaman akuifer dan luas ruang terbuka hijau.
\end{abstract}

Kata Kunci: Akuifer, Bebas, MATLAB, Air bawah tanah, Volume air bawah tanah.

[Title: Prediction of Free Aquifer Volume in Bukit Raya District using Finite Difference Method] A research about prediction of unconfined aquifer in Distrcit Bukit Raya have been done by using finite difference method. The depth of unconfined aquifer data using contour grid District Bukit Raya in 2015 solved numerically by using computer program MATLAB application R2009a version. The aim of this research was to analyze the effect of population growth on the volume of unconfined aquifer in District Bukit Raya. The result of the research could be informed to District Bukit Raya as follows : the total volume of underground water in 2017 in the amount of 10.399.615,33 $\mathrm{m} 3$ and in 2021 in the amount of 10.931.060,63 m3. the volume of underground water that taken by residents in 2017 were in the amount of $5.038 .007,328 \mathrm{~m} 3$ and in 2021 were in the amount of $5.334 .525,03 \mathrm{~m} 3$. The inreasing of lowering the volume of underground water (residue), so that in 2017 The inreasing of loweringthe volume of underground wateras much as5.361.608 m3and in 2021 as much as 5.596.535,6 m3. It can be concluded that the volume of underground waterinfluenced by the changes of the dept of aquifer and the large of green open space

Keywords: Aquifer, Unconfined, MATLAB, Underground water, the volume of underground water

\section{PENDAHULUAN}

Air bawah tanah adalah air yang menempati rongga dalam lapisan batuan atau formasi geologi seperti sungai bawah tanah, air sumur dll. Air bawah tanah dapat di temukan pada lapisan jenuh air atau akuifer,namun perlu disadari bahwa keberadaan air bawah tanah sangat terbatas menurut ruang dan waktu baik menurut kualitas dan kuantitas (Bouwer, 1978)

Keberadaan ABT (Air Bawah Tanah) sangat tergantung besarnya curah hujan dan besarnya air yang dapat meresap kedalam tanah. Faktor lain yang mempengaruhi adalah kondisi litologi (batuan) dan geologi setempat.Hampir semua curah hujan akan mengalir sebagai limpasan (run off) dan terus ke laut. Faktor lainnya adalah perubahan lahan-lahan terbuka menjadi pemukiman dan industri, penebangan hutan tanpa kontrol, hal tersebut akan sangat mempengaruhi infiltrasi terutama bila terjadi pada daerah resapan (recharge area).
Resapan air bawah tanah merupakan faktor yang sangat penting pada proses terbentuknya air bawah tanah yang berfungsi sebagai penyeimbang atau penentu terpeliharanya kelestarian air bawah tanah. Air bawah tanah merupakan salah satu sumber daya air yang paling baik untuk air bersih untuk memenuhi kebutuhan hidup masyarakat.

Pengambilan air tanah yang banyak dan melampaui jumlah rata-rata akibat persaingan berbagai kepentingan dapat menyebabkan penurunan permukaan air tanah secara kontinu dan pengurangan potensi air tanah di dalam akuifer, hal ini akan memicu terjadinya dampak negatif seperti instrusi air laut, penurunan kualitas air tanah, dan penurunan permukaan tanah (Rejekiningrum, 2005; Winter et al., 2005).

Jumlah kebutuhan air bawah tanah untuk penduduk sangat ditentukan oleh tingkat pola kehidupan dari masyarakat pemakainya. Pemanfaatan air bawah tanah untuk domestik 
dihitung berdasarkan standar dari tim penyusunan direktorat tata kota dan tata daerah direktorat masalah bangunan (1983), pemanfaatan air untuk domestik di daerah perkotaan 0,135 $\frac{\mathrm{m}^{3}}{\text { orang }}$ / hari.

Kecamatan Bukit Raya terdir dari 4 Kelurahan, 57 RW dan 240 RT. Tahun 2014 di Kecamatan Bukit Raya terdapat 23.099 kepala keluarga.Jumlah penduduk Kecamatan Bukit Raya mencapai 97.950 jiwa pada tahun 2014. Angka ini mengalami peningkatan sebesar 1,44\% dari tahun 2013. Kepadatan penduduknya mencapai 4,442 jiwa $/ \mathrm{km}^{2}$, dengan kelurahan terpadat adalah Tangkerang Utara sebesar 8,581 jiwa $/ \mathrm{km}^{2}$. Peta Kecamatan Bukit Raya dapat dilihat pada Gambar 1

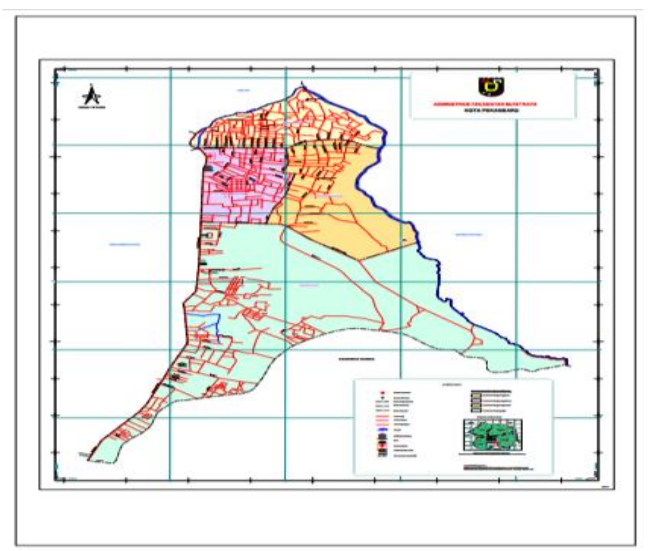

Gambar 1. Peta Kecamatan Bukit Raya (Dinas Pertambangan Kota Pekanbaru)

Lapisan tanah atau batuan yang dapat menangkap dan meloloskan air adalah akuifer (Chay, 2002). Kondisi sistem akuifer di dalam tanah sangat rumit, namun dapat dipelajari dan diprediksi keberadaannya, pada musim hujan kandungan air pada akuifer meningkat sedangkan pada musim kemarau kandungan air menurun atau tidak ada sama sekali.Akuifer membentang sangat luas, menjadi semacam reservoir bawah tanah.Pengisian akuifer ini dilakukan oleh resapan air hujan kedalam tanah.Akuifer dibedakan menjadiakuifer terkekang dan akuifer bebas.

Akuifer tertekan/terkekang (confined aquifer) adalah lapisan rembesan air yang mengandung kandungan ABT yang bertekanan lebih besar dari tekanan udara bebas/tekanan atmosfir, sedangkan Akuifer bebas/tak tertekan (unconfined aquifer) adalah lapisan rembesan air yang mempunyai lapisan dasar kedap airsehingga kandungan ABT yang bertekanan sama dengan tekanan udara bebas/tekanan atmosfir. Jenis jenis akuifer dapat dilihat pada Gambar 2.

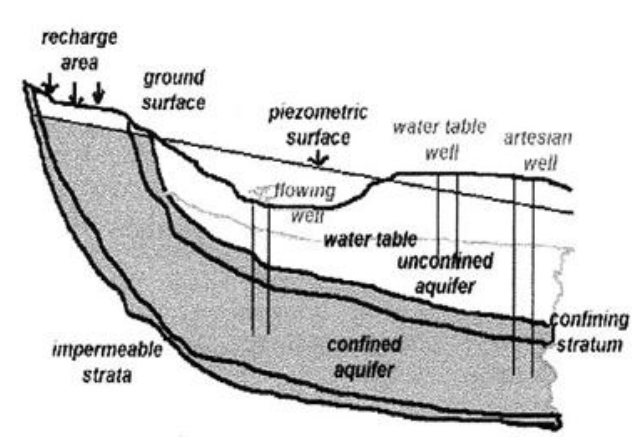

Gambar 2. Jenis jenis akuifer

Pengisian akuifer dilakukan oleh resapan air hujan kedalam tanah.Air meresap pada daerah yang disebut daerah resapan air.Daerah resapan (recharge) disebut sebagai daerah dimana arah aliran air tanah menjauhi permukaan, daerah ini sangat penting dalam mengestimasi sumber air bawah tanah dan penentuan daerah konservasi daerah resapan.Perhitungan resapan air bawah tanah perlu mempertimbangkan sifat fisik batuan/tanah dan lokasi yang ada. Besarnya resapan ini dapat dihitung dengan persamaan (1) (Binnie dan Partners, 1984):

$$
R=P C \times A \times C r
$$

Resapan air bawah tanah hanya salah satu faktor dalam keberadaan air bawah tanah, selain itu faktor faktor lain diantranya adalah: Konduktivitas hidrolika, Strotativitas, Transmisivitas, dimana parameter-parameter akuifer tersebut didapatkan dari karakeristik litologi berdasarkan interpretasi data geolistrik (Todd, 1980).

Simulasi numerik adalah suatu teknik untuk menentukan solusi dari persamaan differensial aliran air bawah tanah. Metode numerik yang digunakan adalah metode beda hingga (Finite Difference Method). Metode beda hingga adalah suatu metode untuk mendiskritisasi persamaan differensial menjadi persamaan linier.Proses diskritisasi persamaan differensial yang dicari meliputi penggantian setiap turunan pada titik-titik dari ordering yang dilakukan (x_i,y_i ) dengan rumus beda hingga yang bersesuaian.Agar pembentukan persamaan beda hingga menjadi mudah, maka perlu dibentuk suatu jaringan bujur sangkar seragam (squaremesh)seperti ditunjukkan pada Gambar 3. 


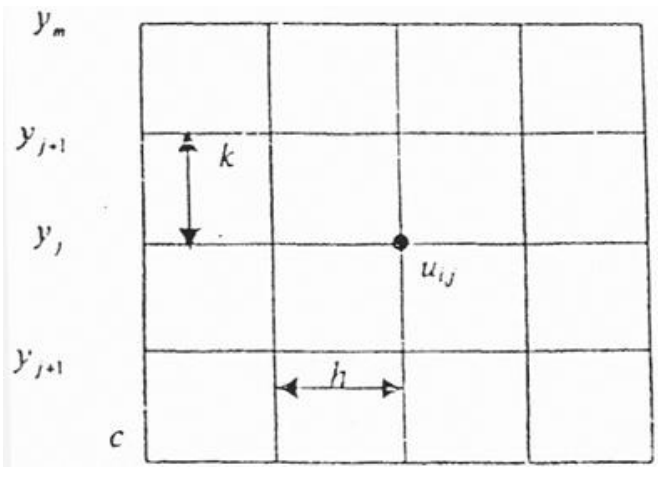

Gambar 3. Squaremesh secara umum

Kondisi unstedy state atau tidak tunak ini adalah suatu kondisi dimana jumlah air bawah tanah yang masuk (recharge) tidak sama dengan jumlah yang keluar (discharge), hal ini berarti telah terjadi gangguan terhadap sistem alamiah aliran air bawah tanah, yang mana diakibatkan oleh eksploitasi air bawah tanah yang berlebihan karena tingginya aktivitas industri maupun tingginya laju pertumbuhan penduduk dan terbatasnya lahan terbuka hijau sebagai daerah resapan air (M. Juandi dan M. Sarkowi, 2016).

Persamaan differensial air bawah tanah untuk kondisi unsteady state merupakan teori yang akan dikembangkan dalam penelitian ini dilihat adanya beberapa parameter yang dapat dianggap sebagai suatu konstanta, maka untuk memudahkan persamaan akan menjadi:

$\frac{\partial h}{\partial t}=b_{1}\left[\frac{\partial^{2} h}{\partial x^{2}}+\frac{\partial^{2} h}{\partial y^{2}}\right] \pm a_{1}$

$a_{1}=\frac{\beta}{A}$

$A=\frac{S}{T}$

$b_{1}=\frac{1}{A}$

$\beta=\left[\frac{R}{T}\right]$

$\lambda=\frac{b_{1} \times \Delta t}{(\Delta x)^{2}}$

$c=a_{1} \times \Delta t$.

Volume air bawah tanah merupakan banyaknya air bawah tanah yang menempati lapisan bawah permukaan bumi, volume air bawah tanah dapat dituliskan dengan persamaan:

$V=h \times A_{r}$

$h$ didapatkan dari penyelesaian persamaan numerik dengan menggunakan software pemprograman yang dapat menyelesaikan persamaan differensial, dimana data yang digunakan untuk menentukan kedalaman dari akuifer berupa data mentah.Data mentah dari kedalaman akuifer kecamatan bukitraya berbentuk matriks yang akan diselesaikan secara numerik.

\section{METODE PENELITIAN}

Metode yang digunakan dalam penelitian ini adalah metode beda hingga dan penelitian dilakukan di Kecamatan Bukit Raya Kota Pekanbaru. Alat dan bahan yang digunakan dalam penelitian ini meliputi peta geologi, dan software numerik berupa MATLAB R2009a dan Microsoft Excel.

\section{HASIL DAN PEMBAHASAN}

Hasil yang diperoleh dari penelitian yang diperoleh adalah Volume Air Bawah Tanah Total,Volume Air yang diambil Penduduk, serta Penurunan Volume (Residu Air Bawah Tanah) menggunakan Metode Beda Hingga yang diselesaikan secara Numerik menggunakan software MATLAB R2009a.

Pengambilan air bawah tanah oleh penduduk dari tahun 2017 sampai 2021 mengalami peningkatan, peningkatan pengambilan air bawah tanah oleh penduduk ini dipengaruhi pertambahan jumlah penduduk tiap tahunnya, sehingga grafik pengambilan air bawah tanah oleh penduduk merupakan grafik peningkatan yang linier. Grafik peningkatan ini dapat dilihat pada Gambar 4.

Grafik pengambilan air bawah tanah oleh penduduk yang meningkat dari tahun ke tahun memenuhi suatu persamaan garis $y=74.129,425(x-$ $2017)+5.038 .007,328$. 


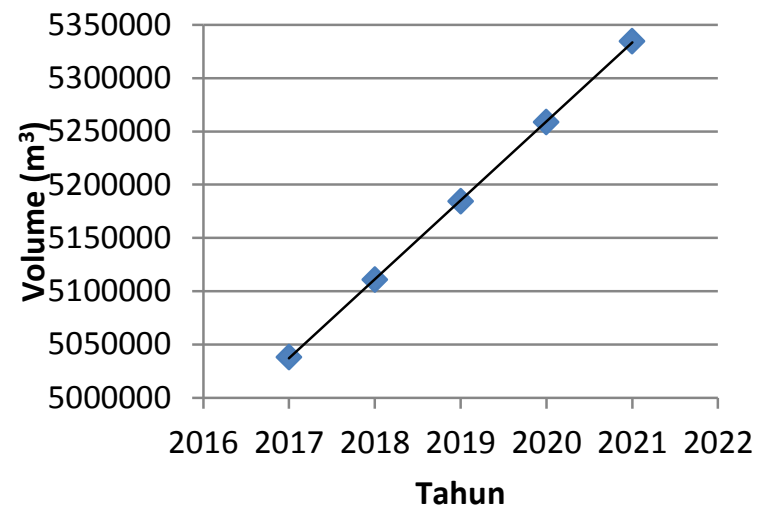

Gambar 4. Grafik prediksi pengambilan air bawah tanah oleh penduduk dari Tahun 2017 sampai 2021

Persamaan garis yang diperoleh dapat dijadikan referensi untuk simulasi air bawah tanah yang diambil penduduk setiap tahun dengan cara mengganti nilai dari variable $\mathrm{x}$ dengan tahun yang ingin ditentukan.

Hasil simulasi kedalaman akuifer bebas Kecamatan Bukit Raya didapat dari menyelesaikan Matriks Grid kedalaman Kecamatan Bukit Raya dengan menggunakan Program MATLAB, sehingga didapat kedalaman simulasi dari akuifer bebas Kecamatan Bukit Raya.Hasil simulasi kedalaman akuifer bebas Kecamatan Bukit Raya dari Tahun ke Tahun mengalami peningkatan penurunan kedalaman akuifer bebas, hal ini disebabkan karena pengambilan air bawah tanah yang meningkat oleh penduduk setiap tahunnnya, sehingga penurunan kedalaman akuifer bebas dari tahun ke tahun juga akan mengalami peningkatan. Peningkatan penurunan kedalaman akuifer bebas Kecamatan Bukit Raya dari Tahun 2017 sampai 2021.Grafik penurunan kedalaman akuifer bebas dari tahun 2017 sampai 2021 dapat dilihat pada Gambar 5.Grafik penurunan kedalaman akuifer bebas Kecamatan Bukit Raya setiap tahunnya mengalami peningkatan dengan persamaan $\mathrm{y}=0,010275(\mathrm{x}-2017)+0,938, \mathrm{R}^{2}$ $=0,968$.

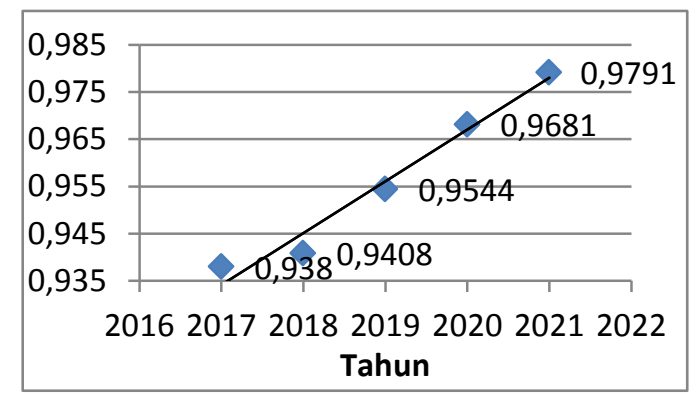

Gambar 5.Grafik peningkatan penurunan kedalaman akuifer bebas Kecamatan Bukit Raya dari Tahun 2017 sampai 2021.
Persamaan garis yang diperoleh dapat digunakan untuk menentukan peningkatan penurunan kedalaman akuifer bebas Kecamatan Bukit Raya pada tahun mendatang.

Hasil peningkatan penurunan kedalaman akuifer bebas Kecamatan Bukit Raya kemudian digunakan untuk memprediksi peningkatan penurunan volume akuifer bebas (Residu). Volume residu dihitung dengan menggunakan persamaan, dimana untuk nilai RTH (Ar) digunakan nilai yang konstan, sehingga diperoleh hasil grafik hubungan antara peningkatan penuruna volume ABT terhadap tahun pada Gambar 6.

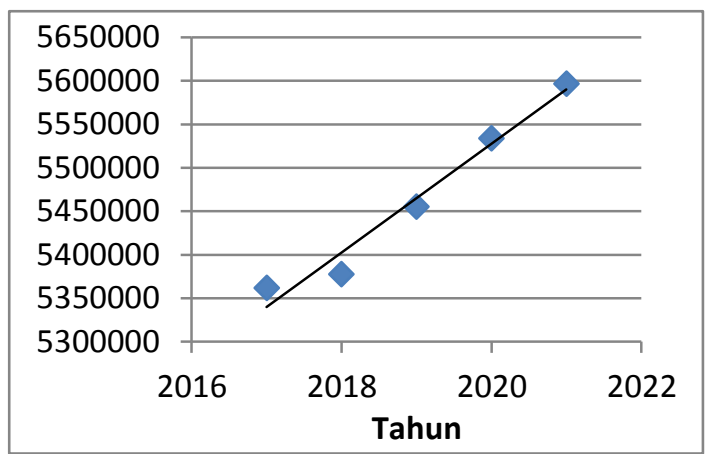

Gambar 6.Grafik residu volume air bawah tanah Kecamatan Bukit Raya dari Tahun 2017 sampai 2021

Grafik peningkatan penurunan Volume air bawah tanah (residu) volume air bawah tanah meningkat setiap tahunnya sehingga dari grafik tersebut didapat persamaan garisy $=58.731,9(\mathrm{x}$ $2017)+5.361 .608$ dan korelasi sebesar $R^{2}=0,968$. Persamaan garis yang diperoleh dapat digunakan untuk menentukan penurunan volume air bawah tanah (residu) Kecamatan Bukit Raya pada tahun mendatang.

Volume total air bawah tanah setiap tahunnya didapat dari kalkulasi air bawah tanah yang diambil oleh penduduk setiap tahun dengan peningkatan penurunan ABT setiap tahunnya, sehingga diperoleh hasil volume air bawah tanah total, sehingga dapat diperoleh hasil grafik hubungan antara peningkatan penuruna volume total ABT terhadap tahun.Grafik volume total akuifer bebas dari tahun 2017 sampai 2021 dapat dilihat pada Gambar 7. 


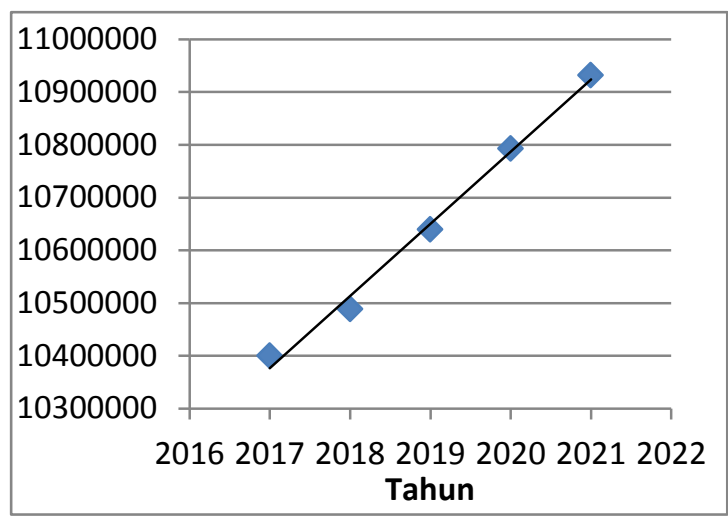

Gambar 7. Grafik volume total ABT Kecamatan Bukit Raya dari tahun 2017 sampai 2021

grafik ini merupakan grafk yang linier dan memiliki persamaan garis $\mathrm{y}=132.861,325(\mathrm{x}-$ $2017)+10.399 .615,33$ dan korelasi sebesar $\mathrm{R}^{2}=0,992$. Persamaan garis yang diperoleh dapat digunakan untuk menentukan volume total air bawah tanah Kecamatan Bukit Raya pada tahun tahun mendatang.

Hasil prediksi dari volume total ABT, volume residu dan volume pengambilan air bawah tanah oleh penduduk dapat dilihat pada pada Gambar 8 .

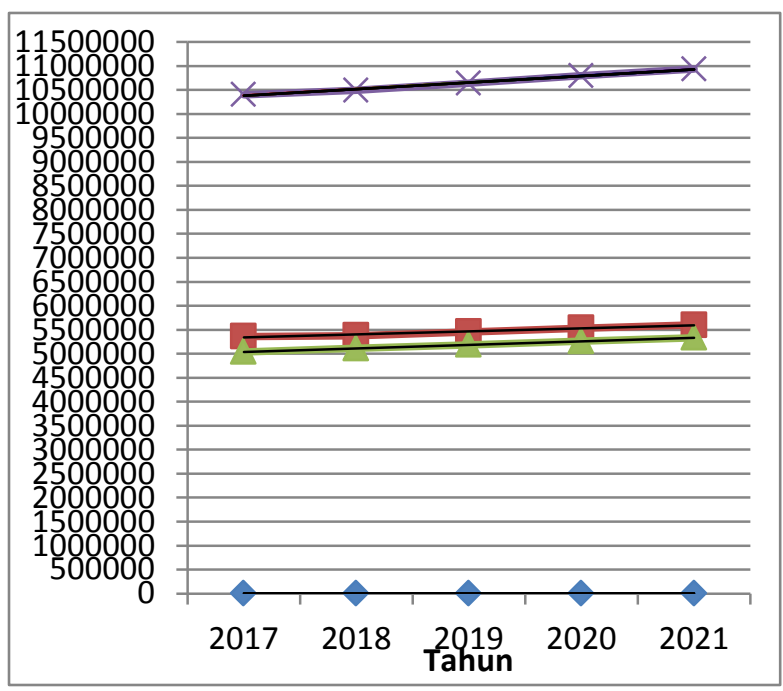

Gambar 8. Hasil Prediksi ABT Kecamatan Bukit Raya dari tahun 2017 sampai 2021

Keterangan:

$x=$ Volume Total ABT

घ = Volume Residu ABT

$\Delta=$ Volume Air yang diambil Penduduk

\section{SIMPULAN DAN SARAN}

Berdasarkan hasil penelitian dan pembahasan, maka dapat diambil kesimpulan Volume total air bawah tanah hasil simulasi mengalami peningkatan penurunan volume total air bawah tanah setiap tahunnya.Peningkatan penurunan volume total air bawah tanah disebabkan oleh meningkatnya pengambilan air bawah tanah oleh penduduk setiap tahunnya. Volume total air bawah tanah pada Tahun 2017 sebesar 10.399.615,33 $\mathrm{m}^{3}$ dan pada Tahun 2021 sebesar 10.931.060,63 m³.

\section{DAFTAR PUSTAKA}

Binnie and Partners, 1984.Applied Hydrogeologi.Third Edition.Prentice Hall Englewood Cliffs. New Jersey

Bouwer, H. 1978. Groundwater Hydrology. Int. Student Ed. McGraw-Hill Kogakusha Ltd.

Chay, A. 2002.Hidrologi dan Pengelolaan Daerah Aliran Sungai.Penerbit Gadjah Mada Yogyakarta. University Press

M Juandi, M Sarkowi, 2016 .2D Groundwater Depth for Analysis of The Zone Unconfined Aquifer ,INSIST.Volume 1, Issue. 1.

Rejekiningrum. P., Y. Apriyana, dan F. Ramadani. 2005. PendayagunaanSumberdaya Air untuk Pengembangan Kapas di SulawesiSelatan.Balai Penelitian Agroklimat dan Hidrologi.PusatPenelitian dan Pengembangan Tanah dan Agroklimat.BadanPenelitian dan Pengembangan Pertanian.

Todd D.K, 1980. Groundwater Hydrology, 2nded JohnWiley and Sons Inc, New York

Winter, T. C., J. W. Harvey, O. L. Franke, and W. M. Alley. 2005.Concepts of Ground Water, Water Table, and Flow Systems. U.S.Department of the Interior, U.S. Geological Survey. http:/ / ga.water.usgs.gov/edu/watercyclegw discharge. 